\title{
Rapid Early Holocene Deglaciation Of The Laurentide Ice Sheet
}

Anders E. Carlson ${ }^{1 *}$, Allegra N. LeGrande ${ }^{2}$, Delia W. Oppo ${ }^{3}$, Rosemarie E. Came ${ }^{4}$,

Gavin A. Schmidt ${ }^{2}$, Faron S. Anslow ${ }^{5}$, Joseph M. Licciardi ${ }^{6}$, Elizabeth A. Obbink ${ }^{1}$

${ }^{1}$ Department of Geology \& Geophysics, University of Wisconsin, Madison, WI, 53706,

\section{USA}

${ }^{2}$ NASA Goddard Institute for Space Studies and Center for Climate System Research, Columbia University, New York, NY, 10025, USA

${ }^{3}$ Department of Geology and Geophysics, Woods Hole Oceanographic Institution, Woods Hole, MA 02543, USA

${ }^{4}$ Geology \& Planetary Sciences, California Institute of Technology, Pasadena, CA, 91125, USA

${ }^{5}$ Earth and Ocean Sciences, University of British Columbia, Vancouver, BC, V6T 1Z4, Canada

${ }^{6}$ Department of Earth Sciences, University of New Hampshire, Durham, NH, 03824, USA

*corresponding author: acarlson@geology.wisc.edu, 608-262-1921

The early Holocene deglaciation of the Laurentide Ice Sheet (LIS) is the most recent and best constrained disappearance of a large Northern Hemisphere ice sheet. Its demise is a natural experiment for assessing rates of ice sheet decay and attendant contributions to sea level rise. Here we demonstrate with terrestrial and marine records that the final LIS demise occurred in two stages of rapid melting from $~ 9.0$ -

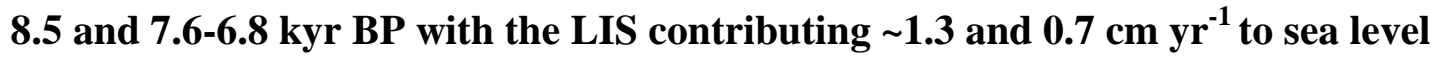
rise, respectively. Simulations using a fully coupled atmosphere-ocean general circulation model suggest that increased ablation from enhanced early Holocene 
boreal summer insolation may have been the predominant cause of the LIS contributions to sea level rise. Although the boreal summer surface radiative forcing of early Holocene LIS retreat is twice that of projections for 2100 C.E. greenhouse gas radiative forcing, the associated summer surface air temperature increase is the same. The geologic evidence for rapid LIS retreat under a comparable forcing provides a prehistoric precedent for a possible large negative mass balance response of the Greenland Ice Sheet by the end of the coming century.

One of the greatest sources of uncertainty in projections of future sea level rise in response to global warming is the melt contribution from the Greenland Ice Sheet ${ }^{1}$. This uncertainty arises in part because the period of direct observations available to create empirical predictions and to test the current generation of ice sheet models is extremely short $^{1-5}$. Examination of past ice sheet-climate interactions provides a record of ice sheet growth and decay longer than modern observations. In particular, the behavior of terrestrial ice sheets under climates warmer than present affords potential insight into the future behavior of the Greenland Ice Sheet. During the early Holocene, enhanced boreal summer insolation $^{6}$ (Fig. 1a) warmed Northern Hemisphere summers by several degrees, presumably driving retreat of the Laurentide Ice Sheet (LIS) $)^{7-9}$. However, portions of the northern and eastern North Atlantic were colder than present ${ }^{10-12}$, possibly as a consequence of the suppression of Labrador Sea deep water production by LIS meltwater $^{13,14}$. The gradual rise in sea level during the early Holocene ${ }^{15-17}$ was punctuated by at least two increases in the rate of sea level rise, which were sourced from either the LIS or Antarctic Ice Sheet, indicating variations in the rate of ice sheet melting ${ }^{14,18,19}$. The early Holocene LIS thus represents the most recent disappearance of a mid- to high-latitude terrestrial ice sheet, and can provide constraints on how fast 
terrestrial ice sheets can melt and raise sea level under a climate warmer than present.

\section{Early Holocene Laurentide Ice Sheet Retreat}

To determine the LIS retreat rate, we compiled minimum limiting radiocarbon dates of deglaciation for Quebec, Labrador, eastern Nunavut ${ }^{20}$ and Hudson Bay ${ }^{21}$, along with cosmogenic ${ }^{10}$ Be ages from Labrador ${ }^{22}$ and Quebec ${ }^{14}$ (Fig. 1c, 2a \& S1). All radiocarbon ages are calibrated, reservoir corrected if marine ${ }^{20,21}$ (Table S1), and presented as straight averages of the oldest dates, which constrain deglaciation as occurring sometime before the deposition of the organic material or shell.

Four marine shell dates place the marine incursion following deglaciation of the northern bank of the St. Lawrence estuary at $11.8 \pm 0.3 \mathrm{kyr}$ BP (Fig. S1). The southern LIS margin likely stabilized near the St. Lawrence, because the oldest terrestrial organic material from southeastern Quebec dates to $8.7 \pm 0.3 \mathrm{kyr}$ BP (2 dates). Farther east, the southern Labrador coast deglaciated before 11.2 \pm 0.4 kyr BP (2 marine dates) with the ice margin remaining near the coast until sometime before $8.6 \pm 0.7 \mathrm{kyr} \mathrm{BP}$ (2 terrestrial dates). Along the northeastern side of the LIS, ${ }^{10} \mathrm{Be}$ dates indicate ice retreat from the northeastern Labrador coastal moraines at $13.4 \pm 1.5 \mathrm{kyr}$ BP (7 dates) and 12.0 $\pm 2.1 \mathrm{kyr}$ BP $(6 \text { dates })^{22}$. The oldest terrestrial radiocarbon dates from near the coast indicate that ice

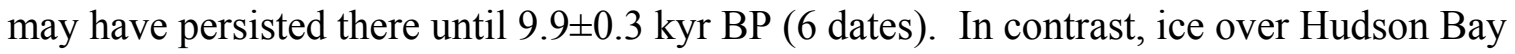
and the western LIS margin continued to thin and retreat during the early Holocene with the only firm chronologic constraint being the collapse of ice over Hudson Bay $8.5 \pm 0.2$ kyr $\mathrm{BP}^{21}$.

Following this collapse, the LIS split into two ice caps: one over Quebec and Labrador, the second over eastern Nunavut and Baffin Island (Fig. 2a). A gap in minimum limiting radiocarbon ages suggests the Quebec/Labrador Ice Cap margins 
subsequently stabilized. The southern Quebec margin resumed northward retreat before 7.5 $\pm 0.2 \mathrm{kyr}$ BP (3 dates) and southern to central Quebec deglaciated before 7.1 $\pm 0.1 \mathrm{kyr}$ BP (2 dates). Three dates from eastern Labrador indicate ice margin retreat resumed before $7.5 \pm 0.1 \mathrm{kyr} \mathrm{BP}$, and western to central Labrador deglaciated before $6.6 \pm 0.4 \mathrm{kyr}$ $\mathrm{BP}$ ( 3 dates). Thirteen ${ }^{10} \mathrm{Be}$ dates and the timing of the marine limit from western Quebec suggest a similar retreat history, with deglaciation of the James Bay coast by $8.0 \pm 0.2 \mathrm{kyr}$ BP followed by margin stabilization ${ }^{14}$. The western margin resumed retreat $\sim 7.4 \mathrm{kyr}$ BP with deglaciation across western to central Quebec $6.8 \pm 0.2 \mathrm{kyr} \mathrm{BP}^{14}$. To the northwest, three marine shell dates place the marine incursion in northeastern Nunavut at 7.2 $\pm 0.1 \mathrm{kyr}$ BP, indicating deglaciation prior to the incursion. Small ice caps likely persisted over northern Quebec and Labrador until some time before 5.7 $\pm 0.2 \mathrm{kyr}$ BP (4 dates) and $5.5 \pm 0.2 \mathrm{kyr} \mathrm{BP}$ (1 date), respectively, and ice over Baffin Island continued to retreat until $\sim 6 \mathrm{kyr} \mathrm{BP}^{23}$. These small ice caps likely constituted $<0.5 \mathrm{~m}$ of sea level rise ${ }^{7}$.

Based on the above chronology, we suggest that two intervals of retreat and enhanced melting of the LIS occurred in the early Holocene, and place the end of significant LIS melting at $6.8 \pm 0.3 \mathrm{kyr}$ BP (Fig. 1c). The onset of the first enhanced retreat period presumably began after the Younger Dryas cold event ended $\sim 11.5 \mathrm{kyr}$ BP and more likely closer to $\sim 9 \mathrm{kyr}$ BP based upon the radiocarbon dates, culminating in the opening of Hudson Bay 8.5 kyr BP (Fig. S2). Much of this early melting was likely focused along the southwestern to western LIS margin and over Hudson Bay, possibly related to the $0.4-0.6 \%$ decrease in Labrador Sea planktonic $\delta^{18} \mathrm{O}$ (Globigerina bulloides) (reduced surface water density) ${ }^{24-26}$ at $\sim 10-8.4 \mathrm{kyr}$ BP with peak $\delta^{18} \mathrm{O}$ depletion $\sim 9$ kyr BP (Fig. 1b). After a period of margin stabilization, which may represent a response to regional reorganization of atmospheric circulation patterns 
following the opening of Hudson Bay ${ }^{14}$ and cooling from the drainage of Glacial Lake Agassiz with attendant reduced Atlantic meridional overturning circulation (AMOC) $)^{12,21,25-27}$, retreat of the LIS resumed $\sim 7.6 \mathrm{kyr}$ BP and ended $\sim 6.8 \mathrm{kyr}$ BP (Fig S2). This latter period of melting may also be reflected in the Labrador Sea as a 0.2-0.3 $\%$ decrease in $\delta^{18} \mathrm{O}$ (Fig. 1b).

\section{Laurentide Ice Sheet Contributions To Sea Level Rise}

We estimate the LIS Holocene sea level rise contribution by converting LIS area ${ }^{20}$ $\left(\mathrm{km}^{2}\right)$, with revised area ages matching our LIS chronology (Fig. S2), to ice volume $\left(\mathrm{km}^{3}\right)$ using the well-established relationship for an ice sheet on a hard bed ${ }^{28}$ $(\log [$ volume $]=1.23[\log [\operatorname{area}]-1])$. Although this assumes an ice sheet is in equilibrium, this relationship was developed on ice sheets and ice caps with both negative and positive mass balances, single and multiple ice domes, a span 4 orders of magnitude in area (Antarctic Ice Sheet to the Barnes Ice Cap), and climate conditions from temperate maritime (Iceland) to polar desert (Antarctica). The error in the volume estimate is $\sim 12 \%$, which places the empirically predicted $11 \mathrm{kyr} \mathrm{BP}$ ice volume in agreement with LIS volumes reconstructed by a physically based steady-state ice sheet model $^{7}$ and an isostatic rebound model $^{15}$.

From 11 to $6 \mathrm{kyr}$ BP, sea level rose at an average rate of $\sim 1 \mathrm{~cm} \mathrm{yr}^{-1}$ largely reflecting melting of the LIS and Antarctic Ice Sheet, with higher rates during the early Holocene than mid Holocene ${ }^{15-17}$ (Fig. 1e). Between 11 and 9 kyr BP, we estimate the LIS contributed $15 \pm 1.8 \mathrm{~m}$ of sea level rise at $0.7-0.9 \mathrm{~cm} \mathrm{yr}^{-1}$ (Fig. $1 \mathrm{~d} \& \mathrm{e}$ ). During the subsequent phase of rapid LIS retreat 9-8.5 kyr BP, the LIS contributed $6.6 \pm 0.8 \mathrm{~m}$ of sea level rise at $\sim 1.3 \mathrm{~cm} \mathrm{yr}^{-1}$. This rate is comparable to geologic evidence for global sea

level rise for this interval derived from coral records ${ }^{16,17}$ (Fig 1d). Estuarine records from 
Chesapeake Bay ${ }^{18}$ also indicate a marsh drowning event $\sim 8.9$ kyr BP not explained by isostasy with sea level rising at $\geq 1.2 \mathrm{~cm} \mathrm{yr}^{-1}$, similar to our estimated rate of sea level rise from the LIS. After $8.5 \mathrm{kyr}$ BP, the remaining $9.2 \pm 1.1 \mathrm{~m}$ of LIS sea level rise was added over $\sim 1.7$ kyrs. The LIS chronology and Labrador Sea $\delta^{18} \mathrm{O}$ records suggest a deceleration of retreat $\sim 8.5-7.6 \mathrm{kyr} \mathrm{BP}$ with a subsequent increase, corresponding to a LIS contribution to sea level rise of $\sim 0.4 \mathrm{~cm} \mathrm{yr}^{-1} 8.5-7.6 \mathrm{kyr} \mathrm{BP}$, increasing to $\sim 0.7 \mathrm{~cm} \mathrm{yr}^{-}$ ${ }^{1}$ 7.6-6.8 kyr BP (Fig. 1d). Accelerated LIS retreat 7.6-6.8 kyr BP corresponds with a second increase in the rate of Holocene sea level rise $\sim 7.6 \mathrm{kyr} \mathrm{BP}^{19}$, when sea level rose $\sim 4.5 \mathrm{~m}$ at $\sim 1.0 \mathrm{~cm} \mathrm{yr}^{-1}$, suggesting that the LIS was also the main source of sea level rise at this time ${ }^{14}$.

\section{Impact Of Early Holocene Climate On The Laurentide Ice Sheet}

To quantify the effects of enhanced boreal summer insolation on the LIS and climate, we simulated the 9 kyr BP climate, with a prescribed LIS ${ }^{7}$ (Fig. 2a), using the fully coupled atmosphere-ocean general circulation model (AOGCM), NASA Goddard Institute for Space Studies ModelE- $\mathrm{R}^{29}$. This model contains a fully coupled surface energy and moisture balance over land ice, but does not include any horizontal ice advection, limiting our analysis to the estimation of the LIS surface mass balance. Additionally, the model tracks water isotopes throughout the hydrologic cycle ${ }^{29}$. To test the skill of the model at simulating $9 \mathrm{kyr}$ BP climate, we compared simulated $\Delta \delta^{18} \mathrm{O}(9$ kyr BP - Pre-Industrial ${ }^{29}(\mathrm{PI})$ ) against a compilation of $\Delta \delta^{18} \mathrm{O}$ from geologic data (Fig. 3c \& f). We compiled Early Holocene (EH, 8-10 kyr BP) and Late Holocene (LH, 3-0 kyr BP) $\delta^{18} \mathrm{O}$ from ice cores, lake cores, and speleothems, and estimated seawater $\delta^{18} \mathrm{O}$ $\left(\delta^{18} \mathrm{O}_{\mathrm{sw}}\right)$ from paired $\mathrm{Mg} / \mathrm{Ca}$-based sea surface temperature (SST) and $\delta^{18} \mathrm{O}_{\text {calcite }}$ measurements on the calcite shells of planktonic foraminifera (Supplementary Online 
material for a full discussion of methods of data model comparison and model results). Simulated $\Delta \delta^{18} \mathrm{O}$ are in agreement with the EH-LH $\Delta \delta^{18} \mathrm{O}\left(\mathrm{R}^{2}=0.83\right)$ (Fig. 3a). Given the coarse resolution of the AOGCM, this correlation between data and predictions provides confidence in the ability of the model to simulate regional aspects of $9 \mathrm{kyr}$ BP climate, hydrology and LIS surface mass balance.

ModelE-R simulates low $\delta^{18} \mathrm{O}_{\text {sw }}$ (Fig. $\left.3 f\right), \delta^{18} \mathrm{O}_{\text {calcite }}$ and reduced sea surface salinity (not shown) across the northern North Atlantic, Labrador Sea and Arctic Ocean related to the negative LIS mass balance and enhanced run-off, in agreement with North Atlantic paleohydrology data ${ }^{12-14,26}$. The alteration in ocean density suppresses deep winter convection in the Labrador Sea, decreasing total AMOC by $\sim 15 \%$ relative to present, also in agreement with interpretations of Labrador Sea deepwater proxies ${ }^{13}$. Reduced AMOC yields relatively cooler temperatures over the Labrador Sea $\left(1-2{ }^{\circ} \mathrm{C}\right.$ in the winter, $0.5-1{ }^{\circ} \mathrm{C}$ in the summer) extending eastward into the northern North Atlantic (Fig. $3 b$ \& d), matching early Holocene paleoclimate reconstructions ${ }^{10,11}$. Further contributing to cooler temperatures is the influence of LIS elevation and albedo, with surface air temperature (SAT) up to $13.5^{\circ} \mathrm{C}$ cooler over the ice sheet in the summer, of which $1-2{ }^{\circ} \mathrm{C}$ is due to the ice albedo effect (Fig. 3b). The high-pressure system over the LIS maintains an anti-cyclone, reversing wind patterns over Canada (Fig. S3a). The LIS topography forces the mid-latitude jet southward and increases the jet strength (Fig. S3b). Outside of the northern North Atlantic, the Northern Hemisphere summer SST and SAT rise in response to enhanced boreal summer insolation (Fig. 3b \& d), amplified by a $\sim 5 \%$ reduction in Arctic summer sea ice (Fig. 3e).

The $9 \mathrm{kyr}$ BP simulated annual LIS surface mass balance is $-260 \mathrm{~cm} \mathrm{yr}^{-1}$, with accumulation zones centered over Quebec, Labrador and eastern Nunavut (Fig. 2b). 
Much of the LIS mass reduction is over Hudson Bay where low-elevation ice is lost at rates ranging 11-71 $\mathrm{mm}$ day $^{-1}$, in reasonable accord with our inferences from the LIS chronology. Integrating this LIS mass loss from 9 to $8.5 \mathrm{kyr}$ BP results in $\sim 6 \mathrm{~m}$ of sea level rise at $\sim 1.3 \mathrm{~cm} \mathrm{yr}^{-1}$, similar to estimates from the LIS chronology (Fig. 1).

\section{Implications For Future Sea Level Rise}

The agreement between our interpretations from geologic data and the 9 kyr BP AOGCM that does not include ice dynamics suggests that ice sheets (i.e. the LIS) may have melted rapidly in the past. The inclusion of ice dynamics (e.g., ice streaming) in the 9 kyr BP AOGCM would likely only enhance the melt rate ${ }^{2}$. However, by the early Holocene, much of the LIS was on a hard bed where ice streaming is rare (but not absent), implying that ablation controlled LIS mass balance during this time interval. The AOGCM predicts that a boreal summer shortwave radiative forcing of $\sim 40 \mathrm{~W} \mathrm{~m}^{-2}$ relative to present at the top of the atmosphere ${ }^{6}$ can cause considerable summer warming $\left(1-3^{\circ} \mathrm{C}\right)$, promoting a negative mass balance and accelerated melting of a terrestrial ice sheet. Direct comparison to simulations of 2100 C.E. climate (i.e. Special Report on

Emissions scenario A1B) ${ }^{1}$ is difficult because of a complicated suite of forcings including greenhouse gases, black carbon, ozone, snow albedo, atmospheric $\mathrm{H}_{2} \mathrm{O}$, aerosols and land use $^{30}$. However, the cumulative effect is that the increased downward longwave radiation over the Greenland Ice Sheet (GIS) $\left(\sim 10 \mathrm{~W} \mathrm{~m}^{-2}\right)^{30}$ is roughly half the surface shortwave radiation changes on the LIS at $9 \mathrm{kyr} \mathrm{BP}\left(\sim 20 \mathrm{~W} \mathrm{~m}^{-2}\right)$, but the summer SAT warming (2$\left.4^{\circ} \mathrm{C}\right)^{30}$ is similar in both cases.

Additionally, the different sizes of the early Holocene LIS and the GIS combined with their geographical settings, though they both rest on hard beds predominately above sea level, complicate direct inferences. The GIS is situated in the center of the North 
Atlantic with a greater portion of its margin terminating near the ocean, whereas only the eastern and northern LIS margins were near the coast, with the southwestern margin terminating in proglacial lakes. The modern GIS is also $\sim 3$ times smaller than the LIS at the start of the Holocene $\mathrm{f}^{7,15}$, but the LIS was similar in size $\sim 8$ kyr BP. Currently, ablation, ice streaming and calving control GIS mass loss ${ }^{2}$. However, ice streaming and calving will decrease or cease if the GIS retreats inland ${ }^{4}$, making it more analogous to the LIS $^{7}$. Nevertheless, predictions of the rate of sea level rise from the GIS by the end of this century in the A1B scenario ${ }^{1}$ are 6 to 40 times smaller than the estimated rate of LIS mass loss in the early Holocene. Given the similar summer SAT responses for these two periods, and the geologic evidence for rapid early Holocene LIS retreat, current projections of GIS melt rates for the coming century may be only minimum estimates even without considering positive feedbacks from ice sheet dynamics.

\section{Methods}

We simulate climate using the fully coupled AOGCM NASA Goddard Institute for Space Studies ModelE-R, which includes water isotopes ${ }^{29}$, permitting direct comparison to marine and terrestrial $\delta^{18} \mathrm{O}$ records. Because a true transient simulation from the Last Glacial Maximum -- even assuming that the glacial maximum was in equilibrium -- to $9 \mathrm{kyr} \mathrm{BP}$ is beyond our current computational power, we performed a time-slice simulation of 9 kyr BP climate. Boundary conditions appropriate to 9 kyr BP are prescribed (greenhouse gases, insolation, LIS topography, $40 \mathrm{~m}$ of sea level lowering

and its effects on ocean salinity and $\delta^{18} \mathrm{O}$, and the addition of Glacial Lake Agassiz), with details provided in the Supplementary Online Materials. ModelE-R has a simple ice sheet scheme that includes ice sheet surface albedo and energy, freshwater, and water isotopes, with two snow/ice layers that transfer heat and mass. Net melt is transported 
through a 9 kyr BP-appropriate river routing scheme based on LIS topography and North American isostasy ${ }^{7}$. Ideally, a higher resolution model with ice dynamics would be employed, but these usually use simplified predictions of summer melt and are asynchronously coupled to $\mathrm{GCMs}^{3,4}$, not allowing the ice sheet hydrology to directly communicate with the atmosphere and ocean systems. Within the model, there is an imposed global water balance, which modulates the ice calving term to prevent long-term salinity drift in the ocean, with the Southern and Northern Hemispheres partitioned separately. Thus in the model experiment the negative LIS surface mass balance is compensated by a reduction in Northern Hemisphere iceberg calving from the GIS, and therefore, likely underestimates the total ice sheet impact on ocean outflow. ModelE-R was run for 600 model years with results from the last 100 years averaged and compared to a corresponding 100-year average of the Pre-Industrial ${ }^{29}$. Differences between $9 \mathrm{kyr}$ BP and Pre-Industrial ${ }^{29}$ were calculated using a student-t test at $99 \%$ confidence.

1. IPCC in Climate Change 2007: The Physical Basis $4^{\text {th }}$ Assessment Report, IPCC (eds Solomon, S.D. \& Manning, Qin M.) 18 p. (Cambridge University Press, 2007).

2. Alley, R.B., Clark, P.U., Huybrechts, P. \& Joughin, I. Ice-Sheet and Sea-Level Changes. Science 310, 456-460 (2005).

3. Wild, M., Pierluigi, C., Scherrer, S.C., \& Ohmura, A., 2003. Effects of polar ice sheets on global sea level in high-resolution greenhouse scenarios. J. Geophys. Res. 108, doi: 10.1029/2002JD002451.

4. Ridley, J.K., Huybrechts, P., Gregory, J.M., \& Lowe, J.A., 2005, Elimination of the Greenland Ice Sheet in a High $\mathrm{CO}_{2}$ Climate. J. Climate 18, 3409-3427. 
5. Gregory, J.M., Huybrechts, P., \& Raper, S.C.B., 2004, Threatened loss of the Greenland ice-sheet. Nature 428, 616.

6. Berger, L. \& Loutre, M.F. Insolation values for the climate of the last 10 million years. Quat. Sci. Rev. 17, 211-219 (1991).

7. Licciardi, J.M., Clark, P.U., Jenson, J.W. \& MacAyeal, D.R. Deglaciation of a soft-bedded Laurentide Ice Sheet. Quat. Sci. Rev. 17, 427-488 (1998).

8. Mitchell, J.F.B., Grahame, N.S. \& Needham, K.J. Climate simulations for 9000 years before present: Seasonal variations and effect of the Laurentide Ice Sheet. $J$. Geophys. Res. Atm. 93, 8283-8303 (1988).

9. Pollard, D., Bergengren, J.C., Stillwell-Soller, L.M., Felzer, B. \& Thompson, S.L. Climate simulations for 10,000 and 6,000 years BP. Paleoclimates 2, 183-218 (1998).

10. Kaufman D.S. et al. Holocene thermal maximum in the western Arctic $\left(0-180^{\circ} \mathrm{W}\right)$. Quat. Sci. Rev. 23, 529-560 (2004).

11. Kaplan, M.R. \& Wolfe, A.P. Spatial and temporal variability of Holocene temperature in the North Atlantic. Quat. Res. 65, 223-231 (2006).

12. Came, R.E., Oppo, D.W. \& McManus, J.F. Amplitude and timing of temperature and salinity variability in the subpolar North Atlantic over the past 10 k.y. Geology 35, 315-318 (2007).

13. Hillaire-Marcel, C., deVernal, A., Bilodeau, G. \& Weaver, A.J. Absence of deepwater formation in the Labrador Sea during the last interglacial period. Nature 410, 1073-1077 (2001).

14. Carlson, A.E., Clark, P.U., Raisbeck, G.M. \& Brook, E.J. Rapid Holocene Deglaciation of the Labrador Sector of the Laurentide Ice Sheet. J. Climate 20, 
5126-5133 (2007).

15. Peltier, W.R. Global Glacial Isostasy and the Surface of the Ice-Age Earth: The ICE-5G (VM2) Model and GRACE. Annu. Rev. Earth Planet. Sci. 32, 111-149 (2004).

16. Fairbanks, R.G. A 17,000 year glacio-eustatic sea level record: Influence of glacial melting rates on the Younger Dryas event and deep ocean circulation. Nature 342, 637-642 (1989).

17. Bard, E.B. et al. Deglacial sea-level record from Tahiti corals and the timing of global meltwater discharge. Nature 382, 241-244 (1996).

18. Cronin, T.M. et al. Rapid sea level rise and ice sheet response to 8,200 -year climate event. Geophys. Res. Lett. 34 doi:10.1029/2007GL031318 (2007).

19. Yu, S.-Y., Berglund, B.E., Sandgren, P. \& Lambeck, K. Evidence for a rapid sealevel rise 7600 yr ago. Geology 35, 891-894 (2007).

20. Dyke, A.S. in Quaternary Glaciations-Extent and Chronology Part II Vol. 2b (eds Ehlers, J. \& Gibbard, P.L.) 373-424 (Elsevier, Amsterdam, 2004).

21. Barber, D.C. et al. Forcing of the cold event of 8,200 years ago by catastrophic drainage of Laurentide lakes. Nature 400, 344-348 (1999).

22. Clark, P.U., Brook, E.J., Raisbeck, G.M., Yiou, F. \& Clark, J. Cosmogenic ${ }^{10}$ Be ages of the Saglek Moraines, Torngat Mountains, Labrador. Geology 31, 617-620 (2003).

23. Miller, G.H., Wolfe, A.P., Briner, J.P., Sauer, P.E. \& Nesje, A. Holocene glaciation and climate evolution of Baffin Island, Arctic Canada. Quat. Sci. Rev. 24, 1703-1721 (2005).

24. Hillaire-Marcel, C. \& Bilodeau, G. Instabilities in the Labrador Sea water mass 
structure during the last climatic cycle. Can. J. Earth Sci. 37, 795-809 (2000).

25. Hillaire-Marcel, C., deVernal, A. \& Piper, D.J.W. Lake Agassiz final drainage event in the northwest North Atlantic. Geophys. Res. Lett. 34 doi:10.1029/2007GL030396 (2007).

26. Keigin, L.D., Sachs, J.P., Rosenthal, Y. \& Boyle, E.A. The 8200 year B.P. event in the slope water system, western subpolar North Atlantic. Paleoceanography 20, doi: 10.1029/2004PA001074 (2005).

27. LeGrande, A.N. et al. Consistent simulations of multiple proxy responses to an abrupt climate change event. Proc. Natl. Acad. Sci. 103, 837-842 (2006).

28. Paterson, W.S.B. The Physics of Glaciers (Butterworth-Heinemann, Oxford, UK, 1994).

29. Schmidt, G.A., LeGrande, A.N. \& Hoffmann, G. Water isotope expressions of intrinsic and forced variability in a coupled ocean-atmosphere model. J. Geophys. Res. Atm. 112, doi:10.1029/2006JD007781 (2007).

30. Hansen, J. et al. Dangerous human-made interferences with climate: a GISS modelE study. Atmos. Chem. Phys. 7, 2287-2312 (2007).

Acknowledgements. We would like to thank J. Stoner for discussion of Orphan Knoll cores, and L. Keigwin and L. Skinner for sharing data. This research was funded by National Science Foundation grants ATM-05-01351 \& ATM-05-01241 to D.W.O. \& G.A.S., start-up funds from the University of Wisconsin-Madison and a Woods Hole Oceanographic Institution Postdoctoral Scholarship to A.E.C., and the Woods Hole Oceanographic Institution's Ocean and Climate Change Institute (D.W.O. \& R.E.C.). 
Author Contributions. A.E.C. compiled terrestrial and marine records of LIS retreat. A.N.L. \& G.A.S. developed the AOGCM model. A.N.L. initiated and analyzed the $9 \mathrm{kyr}$ BP simulations. A.N.L., G.A.S., A.E.C. \& J.M.L. designed model boundary conditions. A.E.C., R.E.C., E.A.O. \& D.W.O. compiled oxygen isotope data. A.N.L., A.E.C. \& F.S.A. interpreted LIS mass balance. All authors collaborated on the text.

Author Information. Correspondence and requests for materials should be addressed to A.E.C.

Figure 1. Early Holocene Terrestrial and Marine Records. (a) $60^{\circ} \mathrm{N}$ June insolation ${ }^{6}$. (b) G. bulloides $\delta^{18} \mathrm{O}_{\mathrm{c}}$ records with ice volume removed ${ }^{16}$ from southwestern Labrador Sea (circles: MD95-2024, 50.21 ${ }^{\circ} \mathrm{N}, 45.69^{\circ} \mathrm{W}$, water depth $3539 \mathrm{~m}^{24}$, triangles: MD99$2237,50.20^{\circ} \mathrm{N}, 45.68^{\circ} \mathrm{W}$, water depth $3530 \mathrm{~m}^{25}$ ). (c) LIS deglaciation relative to Latitude North: acronyms are $\mathrm{HB}=\mathrm{Hudson}_{\mathrm{Bay}}{ }^{21}, \mathrm{WQ}=$ western Quebec $^{14}, \mathrm{SQ}=$ southern Quebec $^{20}, \mathrm{CL}=$ central Labrador $^{20}, \mathrm{EN}=$ eastern Nunavut $^{20}$. (d) Rate of sea level rise from the LIS. (e) Relative sea level data (triangles from Barbados ${ }^{16}$, circles from Tahiti $^{17}$ ) and changes in LIS volume (black line). Gray bars denote periods of increased LIS melting.

Figure 2. Laurentide Ice Sheet Topography and Mass Balance. (a) LIS topography ${ }^{7}$ (m) used as AOGCM input with regions labeled and the locations of MD95-2024 \& MD99-2237. (b) ModelE-R simulated annual mass balance predicted ( $\mathrm{mm} \mathrm{day}^{-1}$ ) with the black lines denoting the equilibrium line. 
Figure 3. ModelE-R Output Delta Maps between 9 kyr B.P. and PI. (a) Comparison between paleo- $\Delta \delta^{18} \mathrm{O}$ precipitation and seawater changes between the Early Holocene (EH) and Late Holocene (LH) (see 3c and 3e for locations) and ModelE-R 9 kyr BP-PI predicted changes. Dashed line is 1:1 relationship. See Table S2 for data. (b) ModelE-R $\Delta$ SAT summer. (c) ModelE-R $\Delta \delta^{18} \mathrm{O}_{\mathrm{pr}}$ annual (ice volume removed). (d) ModelE-R $\Delta$ SST summer. (e) ModelE-R $\Delta$ summer sea ice extent. (f) ModelE-R $\Delta \delta^{18} \mathrm{O}_{\text {sw }}$ annual (ice volume removed). 


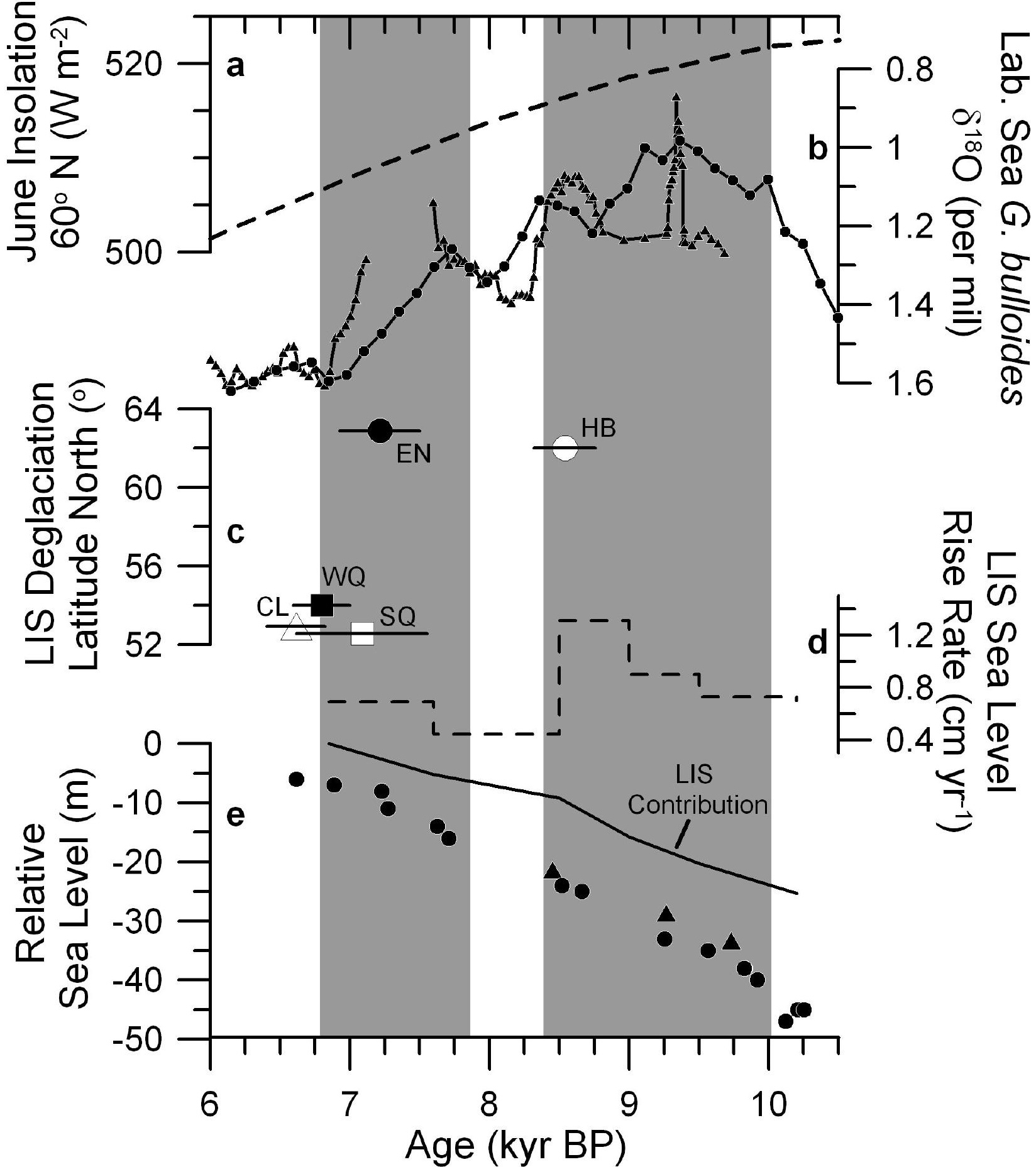




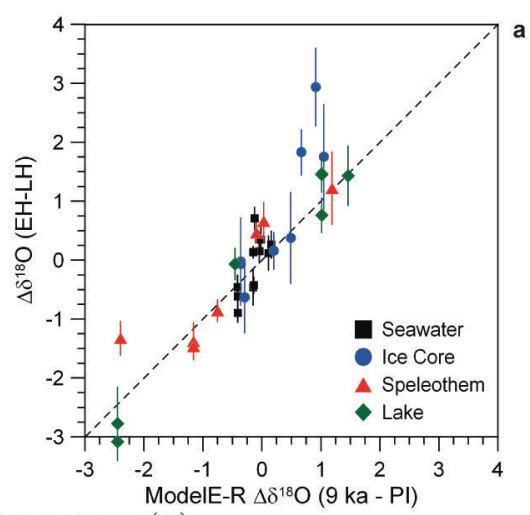

$\triangle 9 \mathrm{~K}$ JJA SAT (C)

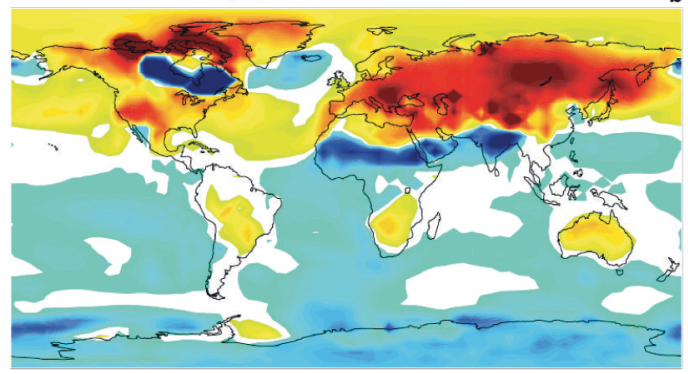

$\triangle 9 \mathrm{~K}$ JJA SST (C)

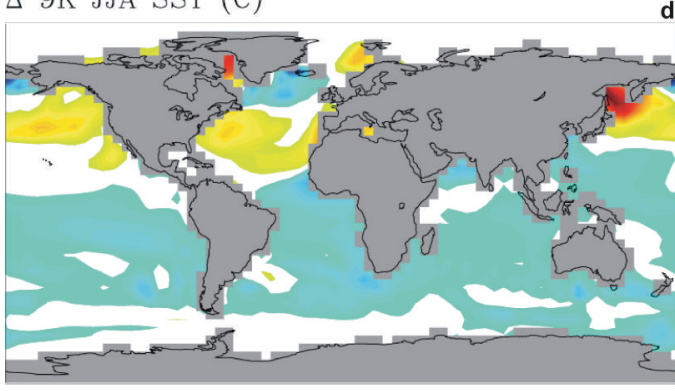

$-5.7-3.6-2.7-1.8-1-.4 \quad 3.81 .21 .82 .4 \quad 33.54 .14 .5$

b $\quad \triangle 9 \mathrm{~K} \mathrm{JJA} \mathrm{ICE}(\%)$

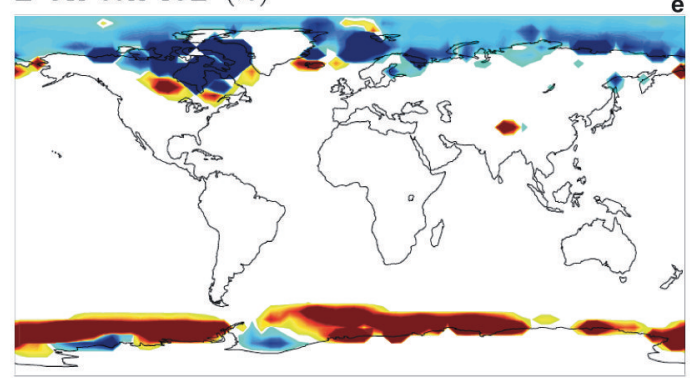

$-12.9-3.4-2.5-1.6-.9-.3 \quad 3.81 .21 .82 .433 .54 .113-98.5-3.4-2.5-1.6-.9-.3 \quad 3 \quad 81.21 .82 .433 .54 .76 .9$

$\triangle 9 \mathrm{~K}$ ANN $\delta^{18} \mathrm{O}_{\mathrm{pr}}$ (permil)

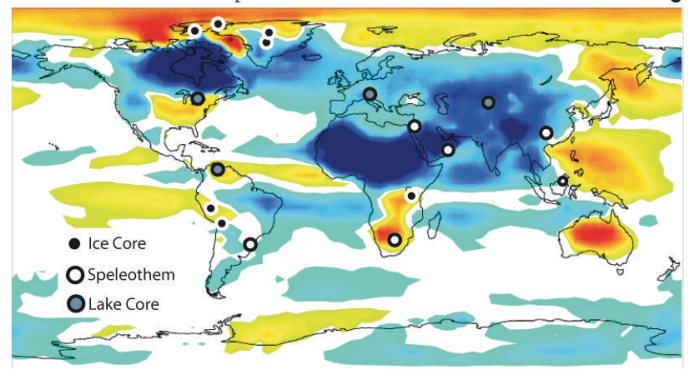

$\triangle 9 \mathrm{~K}$ ANN $0 \mathrm{~m} \delta^{18} \mathrm{O}_{\mathrm{sw}}$ (permil)

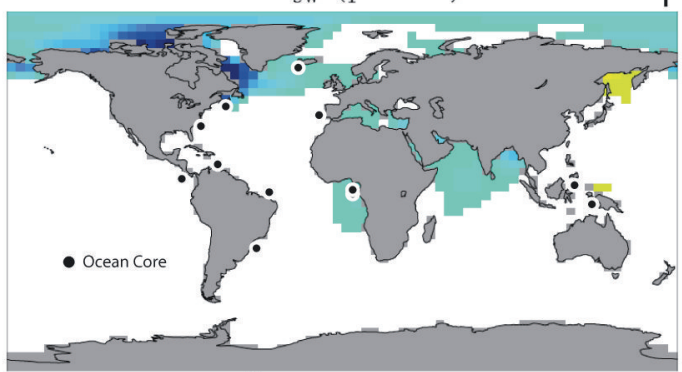

$-10.7-2.3-1.7-1.1-.6-.2 \quad .2 .5 .811 .31 .722 .32 .75 .4$ 